\title{
Parasite fauna of Antarctic Macrourus whitsoni (Gadiformes: Macrouridae) in comparison with closely related macrourids
}

\author{
Julian Münster ${ }^{*}$, Judith Kochmann, Sven Klimpel, Regina Klapper and Thomas Kuhn
}

\begin{abstract}
Background: The extreme, isolated environment within the Antarctic Convergence has fuelled the evolution of a highly endemic fauna with unique adaptations. One species known from this area is the Whitson's grenadier Macrourus whitsoni (Regan, 1913). While closely related species occurring in the Northern Hemisphere were targets of a variety of studies, knowledge on M. whitsoni is scarce, including not only its ecology but also its parasite fauna. Parasites, an often overlooked but important component of every ecosystem, can provide important insights into host ecology, including feeding habits, food web interactions and distribution patterns. The aim of our study was to increase the currently limited knowledge on the ecology of $M$. whitsoni and its parasite life-cycles.
\end{abstract}

Methods: In this study, parasite fauna and stomach content of 50 specimens of $M$. whitsoni were sampled off Elephant and King George Islands. Fish samples were morphological, food ecological and parasitological examined and parasites morphological and partly molecular identified. To evaluate the findings, results were compared with other macrourid species.

Results: The parasite fauna of M. whitsoni revealed 9 genera and 17 species. Stomach content analysis indicated Amphipoda and Mysida as the primary food source. Considering the parasites of M. whitsoni, the highest diversity was found within the Digenea, while prevalence was highest for the Acanthocephala and Nematoda. The diverse parasite fauna of $M$. whitsoni together with the stomach content analysis, suggests a benthopelagic mode of life. Furthermore, an extensive evaluation of the parasite fauna of species of the Macrourinae was conducted, which is probably the most thorough one yet, to compare the findings with closely related host fish species. A similarity analysis revealed a strong connection between the parasite fauna composition and geographical distribution, with a clear separation between the parasite faunas in fishes sampled in the Pacific and the Atlantic Oceans.

Conclusions: Due to the isolated habitat within the Antarctic Conversion, the parasite fauna of M. whitsoni differs clearly from those of closely related and closely occurring species of the genus Macrourus. Our study revealed an endemically dominated parasite fauna, with parasites often host-specific to M. whitsoni. The comparison with the faunas of other species of the Macrourinae revealed a largely endemic parasite fauna, which emphasizes again the isolated character of the Antarctic shelf regions.

Keywords: Antarctica, Feeding behaviour, Macrourinae, Macrourus whitsoni, Grenadier fish, Parasites, Digenea, Nematoda

\footnotetext{
* Correspondence: muenster@em.uni-frankfurt.de

Goethe-University (GU), Institute for Ecology, Evolution and Diversity,

Senckenberg Biodiversity and Climate Research Centre (BiK-F), Senckenberg

Gesellschaft für Naturforschung (SGN), Max-von-Laue-Str. 13, D-60438

Frankfurt/Main, Germany
} 


\section{Background}

The Macrouridae is, with over 300 species, the dominant benthopelagic deep-sea fish family in terms of species as well as biomass [1-3]. Macrourids occur primarily at the continental slopes in depths between 200 and $2000 \mathrm{~m}$. Some species can also be found in the abyssal plains and only a few inhabit the meso- and bathypelagic zones of the oceans. Macrourids are absent in high Arctic waters $[1,3,4]$. The feeding ecology of macrourids is highly diverse, depending on species, size, depth and the nature of the seabed [2]. Most species feed near the bottom, where they search for prey in the sediments, or hunt benthic Crustacea; only few prey on fish, cephalopods and euphausiids in the water column [2].

The family Macrouridae consists of four subfamilies: Bathygadinae, Macrouroidinae, Macrourinae and Trachyrincinae. While the species richness for three subfamilies is relatively low, the Macrourinae contains 28 genera and over 270 species, including the commercially exploited genera Coryphaenoides and Macrourus [2, 5]. Within the genus Coryphaenoides, species exhibit a cosmopolitan distribution, except in Antarctic waters. Within the genus Macrourus four out of five species ( $M$. caml, M. carinatus, M. holotrachys, M. whitsoni) occur only in the southern hemisphere and one, M. berglax, in the North Atlantic $[3,5,6]$. While species of the North Atlantic have been the targets of a variety of studies (e.g. Coryphaenoides rupestris or Macrourus berglax), other macrourids are not as well studied. This is especially true for the Southern Ocean, where species such as Macrourus whitsoni and M. caml commonly occur within the Antarctic Convergence (except for Falkland Islands) [5].

Studies of fishes often focus on feeding habits. Combined, with their parasite fauna (e.g. parasite diversity and infection rates), these studies allow a better understanding of the host's ecology and can help to elucidate the roles of different groups within food webs $[7,8]$. For instance, metazoan parasites, especially helminths, have evolved complex life-cycles, including several hosts among different trophic levels, and are therefore deeply embedded within food webs [8]. Encircled by the Antarctic Convergence causing geographical and seasonal isolation, the Antarctic is a unique ecosystem, home to a multitude of endemic species that are forming a relatively simple food web consisting of phytoplanktonic primary producers, zooplanktonic primary consumers and a series of predators (e.g. fish, whales, seals, seabirds, detritivores) [9]. Here, parasite fauna and infection patterns of the Whitson's grenadier, M. whitsoni, were assessed and combined with stomach content analysis in an effort to increase our currently limited knowledge of the ecology and parasite life-cycles relevant to this host. Data were then used to compare the parasite fauna of
M. whitsoni with other closely related species within the genera Coryphaenoides and Macrourus; this should help produce a more comprehensive picture of the parasite fauna and the global role of the genera Macrourus and Coryphaenoides in oceanic food webs.

\section{Methods}

\section{Sample collection}

Macrourus whitsoni were sampled in March and April 2012 during the research cruise ANT XXVIII/4 on board of the German $R V$ Polarstern in waters off King George and Elephant Island, Antarctica. Sampling was conducted with a bottom trawl at depths of 420.1 to $479.1 \mathrm{~m}$ with a towing time of $30 \mathrm{~min}$ and a speed of 2.8-4.1 kn (nautical miles/ hour). A total of 50 specimens of $M$. whitsoni were caught and stored at $-40{ }^{\circ} \mathrm{C}$ immediately after capture for subsequent examination at the Institute of Ecology, Evolution and Diversity, Goethe University, Frankfurt, Germany. Prior to examination, each specimen was thawed and taxonomically identified using Gon \& Heemstra [10].

\section{Morphological and parasitological examination}

Total length (TL), preanal length (PAL), total weight (TW) and carcass weight $(\mathrm{CW})$ were measured to the nearest $0.1 \mathrm{~cm}$ or $0.1 \mathrm{~g}$, respectively. First, the eyes, fins, skin, gills as well as the nasal, buccal and branchial cavities were inspected for ectoparasites. Afterwards, the body cavity was opened and the internal organs, i.e. the liver, stomach, pyloric caeca, intestine and gonads, were dissected and checked for endoparasites using a stereomicroscope (Olympus SZ 61, at magnifications of 6.7-45). Stomach contents were removed for content analyses (see below). Parasites were isolated and host tissue was removed. Digenean, monogenean, cestode and acanthocephalan parasites were fixed in $4 \%$ borax buffered formalin, preserved in $70 \%$ ethanol (with $4 \%$ glycerol) and morphologically identified using the existing keys and original descriptions [11-16]. Nematode specimens were directly preserved in absolute ethanol for subsequent molecular identification (see Additional file 1).

\section{Stomach content analyses}

Food items were separated and identified to the lowest possible taxonomic level and grouped into taxonomic categories (e.g. subphylum). The dry weight of full and empty stomachs as well as the dry weight of the different food items and groups were recorded to the nearest $0.001 \mathrm{~g}$. Frequency of occurrence ( $\mathrm{F}$ in \%), numerical percentage of prey $(\mathrm{N}$ in \%) and the weight percentage of prey (W in \%) were calculated following Hyslop [17]. The index of relative importance (IRI) was calculated based on these data [18]. 


\section{Data analyses}

Statistical analyses were performed using the software Graphpad Prism v5.01. Parasitological and ecological terminology follow Bush et al. [19]: prevalence (P) defined as the relative number of fish infected with a specific parasite; intensity (I) as the number of individuals of a particular parasite species in a single infected host (given as a range); and mean intensity (MI) as the average intensity of a particular parasite species among the infected specimens of a particular host species.

\section{Metadata analysis}

The data on the metazoan parasite fauna previously reported from the different macrourid species was collected by means of a search in Google Scholar and cross-checked with the references in the Web of Knowledge. For the search, the names of all known species of Macrourus and Coryphaenoides, along with the keywords "parasite", "Digenea", "Monogenea", "Cestoda", "Nematoda", "Acanthocephala" and "Crustacea", were used. Species names were checked using the World Register of Marine Species (www.marinespecies.org). Only unambiguous records were included. In addition to original publications, Klimpel et al. [20] was also utilized. Parasite species richness was calculated for each fish species and its correlation with the number of publications assessed. For a comparison of the parasite faunas in the different fish species, Bray-Curtis similarities were calculated using presence/absence data for the parasite species; based on these data, hierarchical cluster analysis was performed with the Primer 6 software [21].

Tables list species identified to the species level. Numbers of taxa are given as well, i.e. reflecting identification to order, class, family, genera or species level. However, these taxa counts are most likely an overestimation as unidentified specimens from different studies may have been counted as different taxa although they could be the same. Thus, only parasite unambiguously identified to the species level were used for Bray-Curtis calculations.

\section{Results}

\section{Host biometric data and parasite infection data}

The mean TL and PAL of the 50 examined specimens of Macrourus whitsoni was $23.14 \mathrm{~cm}$ ( \pm standard deviation, SD, $5.0 \mathrm{~cm})$, normality test: $P=0.74)$ and $7.7( \pm 1.7 \mathrm{~cm}$ SD), respectively; the mean TW was $67.2 \mathrm{~g}( \pm 34.9 \mathrm{~g}$ SD) and $\mathrm{CW}=50.9 \mathrm{~g}( \pm 27.7 \mathrm{~g} \mathrm{SD})$. Of the 50 examined fish, $43(\mathrm{P}=84.0 \%)$ were infected with a total of seven genera and ten species of parasite, consisting of 219 individual specimens (Table 1). Digeneans infecting the gastrointestinal tract, had the highest diversity, with a total of

Table 1 Parasite fauna of Macrourus whitsoni. Parasites of M. whitsoni $(n=43)$ sampled in Antarctica (off Elephant and King George Islands). Species marked as unidentified were clearly recognised as distinct species. Shown are the site in host, prevalence (P in \%), mean intensity (MI) and range for intensity (I)

\begin{tabular}{|c|c|c|c|c|}
\hline Parasite & Life-cycle stage & Site in host & $\mathrm{P}(\%)$ & $\mathrm{Ml}(\mathrm{I})$ \\
\hline Monogenea & A & G & 44.0 & $1.9(1-4)$ \\
\hline Macruricotyle clavipes & A & G & 44.0 & $1.9(1-4)$ \\
\hline Unidentified monogenean & A & G & 2.0 & $1.0(1)$ \\
\hline Digenea & A & $\ln , P$ & 28.0 & $2.2(1-7)$ \\
\hline Paralepidapedon dubium & A & $P$ & 2.0 & $4.0(4)$ \\
\hline Paralepidapedon awii & $A$ & $P, \ln$ & 2.0 & $1.0(1)$ \\
\hline Paralepidapedon antacrctica & A & $P$ & 2.0 & $1.0(1)$ \\
\hline Lepidapedon brayi & A & $P$ & 4.0 & $1.0(1)$ \\
\hline Lepidapedon ninae & A & $P$ & 2.0 & $1.0(1)$ \\
\hline Gonocerca phycidis & A & St & 2.0 & $1.0(1)$ \\
\hline Unidentified digenean ${ }^{a}$ & A & In, P, St & 52.0 & $1.6(1-7)$ \\
\hline Nematoda & L & L, St & 52.0 & $1.6(1-6)$ \\
\hline Pseudoterranova decipiens $\mathrm{E}$ & L & & 14.0 & $1.1(1-2)$ \\
\hline Unidentified nematode & L & L, St & 42.0 & $1.7(1-5)$ \\
\hline Cestoda & A & I & 2.0 & $1.0(1)$ \\
\hline Parabothriocephalus johnstoni & A & I & 2.0 & $1.0(1)$ \\
\hline Acanthocephala & L & $\mathrm{BC}$ & 64.0 & $3.2(1-13)$ \\
\hline Corynosoma bullosum & L & $\mathrm{BC}$ & 64.0 & $3.2(1-13)$ \\
\hline
\end{tabular}

Abbreviations: $A$ adult, $L$ larva, $G$ gills, In intestine, $L$ liver, $P$ pyloric caeca, $S$ t stomach ${ }^{\text {a }}$ Presumably five different species 
11 species. Macruricotyle claviceps was the only identified species of monogenean parasitizing the gills of $M$. whitsoni. Larval specimens of the acanthocephalan Corynosoma bullosum were found in the visceral cavity. The nematode Pseudoterranova decipiens E [22] (GenBank: KX378173, KX378174; reference accession number: KF017610.1 [23]), identified by molecular analysis, constitutes a new host record for $M$. whitsoni.

\section{Stomach content analyses}

The stomach content analyses revealed that $92.3 \%$ of the stomachs contained food items belonging to the Crustacea. Overall three food items, i.e. belonging to the Amphipoda, Isopoda and Mysida, were identified. The most frequent preys were amphipods $(\mathrm{F}=30.8 \%$, IRI $=$ 628.32) followed by mysids $(\mathrm{F}=12.8 \%, \quad \mathrm{IRI}=256)$. Isopods were less frequent (Table 2). Due to the advanced state of digestion of most food items, identification to a lower taxonomic level was often not possible.

\section{Comparison of parasites reported from Macrourus spp. and Coryphaenoides spp.}

The search on Google Scholar resulted in 72 publications. In the search, only macrourid species with an already documented parasite fauna were included. The numbers of parasite taxa and publications were highly correlated (Spearman's rank correlation $r=0.862, P<$ 0.001) (Fig. 1). A total of 169 different metazoan parasite taxa were found among the 24 fish species included in the search, with $82(48.5 \%)$ parasite taxa being recorded only from one host species (Table 3 ). A total of 97 taxa (66 identified plus 31 unidentified species) were found reported for the four Macrourus spp. The greatest parasite diversity was found in M. berglax with 50 taxa (34 species) and in $M$. carinatus with 29 taxa (22 spp.) (Table 3, Additional file 2: Table S1). Within the genus Coryphaenoides containing 19 species, a total of 101 different parasite taxa (68 spp.) were recorded. Coryphaenoides rupestris and $C$. armatus, both Atlantic

Table 2 Stomach content of Macrourus whitsoni. Results of stomach content analysis of 47 specimens of M. whitsoni sampled off Elephant and King George Islands, Antarctica. Frequency of occurrence ( $F$ in \%), numerical percentage ( $N$ in $\%)$, weight percentage ( $\mathrm{W}$ in \%) and the index of relative importance (IRI) of the major prey groups are shown

\begin{tabular}{lrrrl}
\hline Prey & $\mathrm{F}(\%)$ & $\mathrm{N}(\%)$ & W $(\%)$ & $|\mathrm{R}|$ \\
\hline Crustacea & 92.3 & 98.3 & 89.3 & $17,315.48$ \\
Amphipoda & 30.8 & 18.0 & 2.4 & 628.32 \\
Mysida & 12.8 & 10.2 & 9.8 & 256.00 \\
Isopoda & 5.1 & 0.7 & 0.3 & 4.98 \\
Unidentified & 84.6 & 69.5 & 86.9 & $13,231.44$ \\
Unidentified & 12.8 & 1.7 & 0.8 & 31.50 \\
\hline
\end{tabular}

species, had the most diverse parasite faunas, with 30 and 25 different taxa, respectively; whereas parasite numbers for species of Coryphaenoides inhabiting the Pacific ranged between 3-8 species. Overall, the most diverse parasite groups were the Digenea with 78 taxa (57 spp.) followed by the Nematoda with 27 taxa (16 spp.). The Acanthocephala had the lowest diversity with only 7 taxa ( $5 \mathrm{spp}$.). Highest numbers of fish hosts were recorded for parasites known to have low host specificity (generalist parasites), e.g. Gonocerca phycidis occurring in 12 different fish species, Glomericirrus macrouri in nine, and Gonocerca haedrichi in seven fish species. Detailed information on the parasite taxa found only in one species or shared among different fish species can be found in Additional file 2: Table S1 [6, 13, 14, 20, 2397]).

The hierarchical cluster analysis based on Bray-Curtis similarity matrix revealed one cluster for species sampled in the Atlantic (plus two species from the North Pacific) (Fig. 2). This main cluster is subdivided into three subclusters. Thus, seven species of Coryphaenoides clustered together with Macrourus spp. In the Atlantic cluster within the genus Macrourus, the species M. carinatus and $M$. holotrachys exhibited the greatest similarity (45.4\%). These were followed by $M$. holotrachys and M. whitsoni (similarity of $35.9 \%$ ) and M. carinatus and M. whitsoni (similarity of $24.5 \%$ ). Overall, M. berglax shared the lowest similarities with the three other Macrourus species (19.1\% with M. carinatus, $8.8 \%$ with $M$. whitsoni and $6.3 \%$ with $M$. holotrachys, respectively), but revealed the greatest similarity with $C$. rupestris (genus Coryphaenoides) (42.2\%). Among the species of Coryphaenoides, the parasite faunas in C. armatus and C. carapinus were identified as being most similar (similarity of $52.4 \%$ ). Apart from the main cluster, two smaller clusters of Coryphaenoides spp. from Pacific waters were found. Here, C. filifer and C. serrulatus had the highest similarity (42.8\%). Coryphaenoides acrolepis showed the most pronounced similarity patterns with $C$. longifilis (15.4\%) with which it formed a cluster, whereas Coryphaenoides serrulatus and C. subserrulatus, occurring in the same waters had a similarity of $36.4 \%$ in their parasite fauna. Coryphaenoides delsolari and $C$. striaturus, did not fit to either of the clusters and showed no similarity with the other species.

\section{Discussion}

As suggested by Polyanskii [98], parasites in higher, Nordic latitudes are often generalists, an assumption that was later on extended upon parasites from Antarctic waters [99]. However, most parasites in the Antarctic and sub-Antarctic regions are endemic and for many of them, fish serve as final hosts [100]. The aim of this study was to investigate the parasite fauna and diet of 


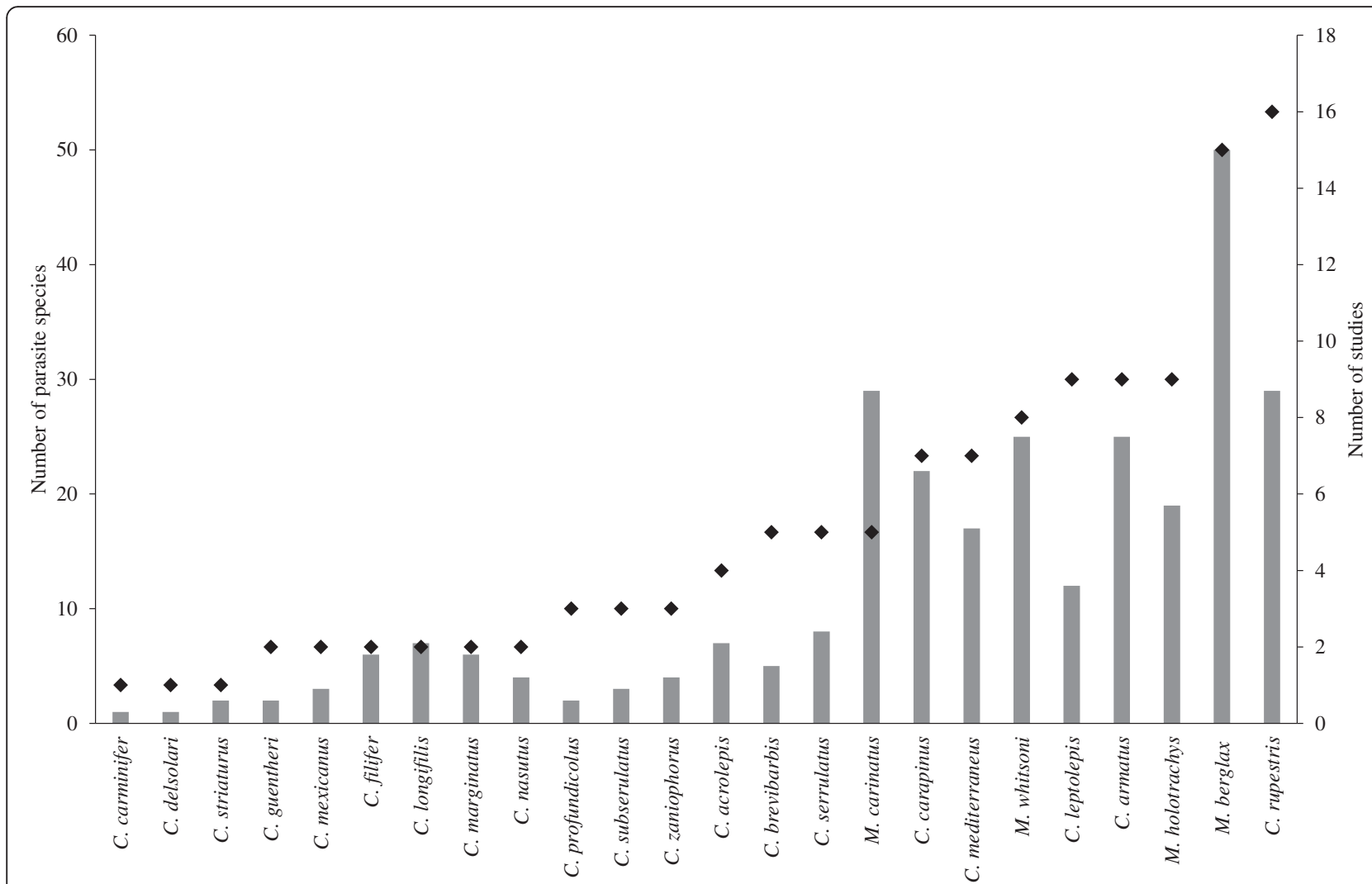

Fig. 1 Parasite fauna and sampling effort. Number of recorded parasite species (grey bars, left $y$-axis) and number of publications on the parasite fauna of the specific fish species (black rhombs, right $y$-axis)

Macrourus whitsoni from the Antarctic region and to compare it with closely related species within the subfamily Macrourinae. Sixteen different metazoan parasite species were found in the 50 specimens of $M$. whitsoni examined. Although a total number of 25 metazoan parasites are known so far from $M$. whitsoni (Additional file 2: Table S1) mainly from studies in the Weddell Sea and off King George Island [49], the numbers found here still suggest that $M$. whitsoni is one of the most diversely parasitized deep-sea fish species. In comparison, only six parasite species are known for Gymnodraco acuticeps (Bathydraconidae) occurring in the same region [101-103]. The parasite fauna of M. whitsoni found in our study consists of taxa with high host specificity and a restricted distribution and is, to our current knowledge, host-specific either for Macrourus spp. or only M. whitsoni. However, some generalist parasites with cosmopolitan distribution were also found. Our literature data search revealed that macrourid species, at least those that are well-studied, have diverse parasite faunas, that might be ascribed to a high biomass of benthic organisms and therefore a high number of potential intermediate hosts in the deep-sea habitats $[20,26]$.
The parasite fauna of $M$. whitsoni consists to a large extent of species only known from Antarctic waters, with some of these parasite species using $M$. whitsoni as their only definitive host $[13,49,50]$. Most of these endemic species are digeneans, also the most diverse group found in this study, with all six identified species maturing in $M$. whitsoni. Digeneans are considered as the most species-rich parasite group in the waters off King George and Elephant Islands, with most of them maturing in teleosts $([49,50,100]$, this study). Forty-five species of digenean are known from these waters, belonging to the superfamilies Hemiuroidea and Allocreadioidea $[50,100]$. Of these, 30 appear to be endemic to Antarctic waters while four are known to be cosmopolitan or bipolar [104]. Only Gonocerca phycidis has a cosmopolitan distribution with a broad host and depth ranges [20,49], whereas the other species found in our study (Lepidapedon brayi, L. ninae, Paralepidapedon awii, P. antarctica and $P$. dubium) are only known from $M$. whitsoni so far $[13,100]$. Thus, they might be endemic to Antarctic waters with distinct host specificity for $M$. whitsoni as suggested previously [49]. Some digeneans, presumably five species, could not be identified, due to their poor condition. Only one nematode, Pseudoterranova decipiens E 
Table 3 Species richness of the major parasite groups in Coryphaenoides spp. and Macrourus spp. Data represent the total number and the number of distinct taxa (Unique) based on the review of the literature

\begin{tabular}{|c|c|c|c|c|c|c|c|c|}
\hline Species & Mono & Dige & Cest & Nema & Acan & Crus & Total & Unique \\
\hline C. acrolepis & 1 & 5 & 0 & 1 & 0 & 0 & 7 & 2 \\
\hline C. armatus & 1 & 12 & 2 & 6 & 0 & 4 & 25 & 7 \\
\hline C. brevibarbis & 1 & 1 & 1 & 0 & 0 & 1 & 4 & 0 \\
\hline C. carapinus & 1 & 11 & 2 & 5 & 1 & 2 & 22 & 4 \\
\hline C. carminifer & 0 & 10 & 0 & 0 & 0 & 0 & 10 & 0 \\
\hline C. delsolari & 0 & 0 & 0 & 0 & 0 & 1 & 1 & 1 \\
\hline C. filifer & 0 & 5 & 0 & 0 & 0 & 1 & 6 & 1 \\
\hline C. guentheri & 0 & 2 & 0 & 0 & 0 & 0 & 2 & 1 \\
\hline C. leptolepis & 0 & 8 & 1 & 0 & 0 & 1 & 11 & 1 \\
\hline C. longifilis & 0 & 2 & 0 & 0 & 0 & 0 & 7 & 3 \\
\hline C. marginatus & 0 & 3 & 0 & 0 & 0 & 3 & 6 & 2 \\
\hline C. mediterraneus & 0 & 8 & 2 & 8 & 0 & 1 & 19 & 4 \\
\hline C. mexicanus & 0 & 2 & 0 & 0 & 0 & 0 & 2 & 0 \\
\hline C. nasutus & 0 & 0 & 0 & 0 & 0 & 4 & 4 & 2 \\
\hline C. profundicolus & 0 & 1 & 0 & 0 & 0 & 0 & 1 & 0 \\
\hline C. rupestris & 1 & 14 & 5 & 6 & 1 & 3 & 30 & 4 \\
\hline C. serrulatus & 4 & 5 & 0 & 0 & 0 & 1 & 10 & 3 \\
\hline C. striaturus & 0 & 9 & 1 & 0 & 0 & 0 & 10 & 1 \\
\hline C. subserrulatus & 2 & 0 & 0 & 0 & 0 & 1 & 3 & 1 \\
\hline C. zaniophorus & 1 & 3 & 0 & 0 & 0 & 0 & 4 & 1 \\
\hline M. berglax & 3 & 16 & 10 & 11 & 3 & 7 & 50 & 19 \\
\hline M. carinatus & 2 & 10 & 5 & 8 & 2 & 2 & 29 & 7 \\
\hline M. holotrachys & 4 & 8 & 0 & 0 & 1 & 6 & 19 & 5 \\
\hline M. whitsoni & 2 & 10 & 4 & 4 & 2 & 3 & 25 & 13 \\
\hline different taxa & 14 & 78 & 18 & 27 & 7 & 25 & 169 & 82 \\
\hline
\end{tabular}

Abbreviations: Mono Monogenea, Dige Digenea, Cest Cestoda, Nema Nematoda, Acan Acanthocephala, Crus Crustacea

[22], could be identified. Pseudoterranova decipiens E can be characterized as a species with low intermediate host specificity in Antarctic waters; its distribution and abundance generally depend on seal populations within the area $[105,106]$. Although this parasite is widely distributed in Antarctic waters and known to occur in other fish intermediate hosts in these waters [107], it has not been found in M. whitsoni before [13, 49, 106]. Thus, it should be considered a new host record. The presence of this parasite indicates demersal feeding behaviour of M. whitsoni, as, contrary to other nematode larvae such as Anisakis spp. or Contracaecum radiatum, larvae of $P$. decipiens are unable to swim and therefore sink to the ground to follow a benthic life-cycle [106, 108]. Within the Acanthocephala, Corynosoma bullosum was the only recorded species in our samples of $M$. whitsoni. This is not surprising as C. bullosum is one of the few species that are typically found on the open-sea shelf, while most acanthocephalans in Antarctic waters are abundant in inshore regions [12] and likely to be absent from deep sea-fish like M. whitsoni. Generally, $C$. bullosum has a circumpolar distribution in the Antarctic and possesses, together with other members of its genus, a relatively complex life-cycle, including Amphipoda, e.g. Bovallia gigantean and Waldeckia obesa as first intermediate host [109, 110]. Apart from M. whitsoni, other fish species, e.g. Chaenocephalus aceratus or Dissostichus eleginoides, can serve as paratenic hosts for this parasite, whereas seals, e.g. Mirounga leonine or Leptonychotes weddellii serve as definitive hosts [12, 111-113]. Confirming earlier findings from the Weddell Sea and off King George Island by Walter et al. [49], the only species of monogenean found in the samples was Macruricotyle clavipes. The Monogenea, as known so far, parasitize only the Macrouridae, mostly Macrourus spp. (M. clavipes, M. holotrachys) in Antarctic and sub-Antarctic waters [49]. Among the cestodes, one adult specimen of Parabothriocephalus johnstoni was found in one individual of $M$. whitsoni. This cestode species seems to be endemic to Antarctic waters and is so far only known from $M$. whitsoni $[49,101]$. 


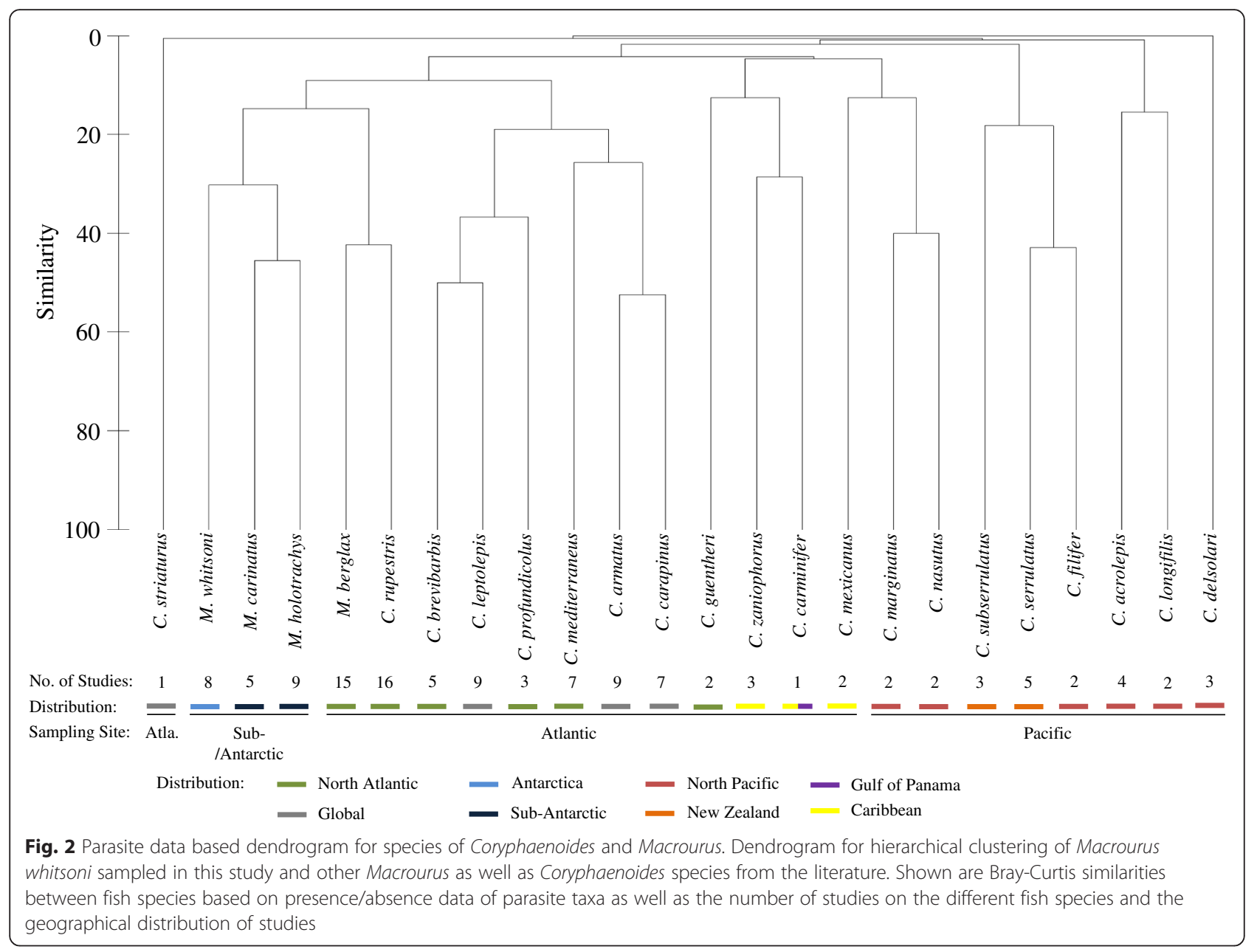

Trophic studies on M. whitsoni are scarce, but it seems that Amphipoda and Euphausiacea are most likely the main preys throughout its life history ([106]; this study). Teleosts, however, were not of importance, although they are reported in the diet of different Macrourus spp. from the Ross Sea slope [114]. One explanation might be an ontogenetic shift in diet when reaching a specific size, thus, fish as prey items might only occur in specimens over TL of $30 \mathrm{~cm}$, which was the maximum length sampled here. These dietary patterns are in accordance with other trophic studies from Antarctic waters where amphipods were recognized as the main food source for many fish species [115]. Crustaceans are important intermediate hosts, especially for nematodes and acanthocephalans, but usually show low infection rates (e.g. Corynosoma bullosum showed a prevalence of $0.49 \%$ in the amphipod Bovallia gigantea and $0.08 \%$ in Waldeckia obesa in the Admiralty Bay and Corynosoma pseudohamanni was found with a prevalence of $0.56 \%$ in the amphipod Cheirimedon femonratus off South Shetland Islands [109, 116, 117]. Therefore, fish preying on crustaceans, such as M. whitsoni, are often only lightly infected (Nematoda: $\mathrm{P}=52.0 \%, \mathrm{MI}=$ 1.65; Acanthocephala: $\mathrm{P}=64.0 \%, \mathrm{MI}=3.22$ ), while piscivorous fish such as Dissostichus eleginoides, an important predator of $M$. whitsoni [118], can be heavily infected [111].

Using presence/absence data for parasite fauna composition and the Bray-Curtis similarity index, macrourid species clustered in one main cluster with species from the Atlantic (and two from the Pacific) and two smaller clusters, including species solely from Pacific waters. This pattern may be explained by the fact that species occurring closely or in the same waters would share more parasite species than species living further apart or in different ocean basins. Considering species in the Atlantic cluster, three subclusters were distinguished. One of these three clusters consisted of one species from the North Atlantic (Coryphaenoides guentheri), two species from Caribbean waters (C. mexicanus and $C$. zaniophorus), one species occurring in the Caribbean as well as Pacific waters off Middle America (C. carminifer) and two species from the Pacific (C. 
marginatus and C. nasutus). The clustering of species solely inhabiting the Pacific with those from the Atlantic might be affected by sampling bias (low sampling effort in the Pacific overall) and an increase of sampling might reveal closer similarities with other species from the Pacific. However, the two Pacific species (C. marginatus and C. nasutus) clustered together with species from the Caribbean and Panama waters and not with other Atlantic species, indicating that distance might play a role for similarity in parasite species. In the case of cosmopolitan fish species, e.g. C. armatus, parasite fauna showed greater similarities with those of fish species from the Atlantic than from the Pacific. However, this might only reflect a sampling bias as most of the studies on these species have taken place in the Atlantic (e.g. C. armatus: $[57,58]$; C. carapinus: $[57,67])$. Species from the Antarctic and sub-Antarctic regions showed greater similarities of their parasite faunas with species from Atlantic rather than Pacific waters. Between both Macrourus spp. inhabiting the subAntarctic and temperate waters around the Antarctic Convergence ( $M$. carinatus: circumpolar; $M$. holotrachys: off the South American coast) [3, 5], the literature data revealed a parasite fauna with only $41.7 \%$ similarity, whereas a more similar fauna in closely related species, occurring in the same marine geographic locality would be expected. One explanation for this dissimilarity might be their different feeding habits. Macrourus carinatus forages in the pelagic realm at depths shallower than $900 \mathrm{~m}$ while M. holotrachys feeds in the demersal zone at depths deeper than $1000 \mathrm{~m}$ [119]. Thus, their niches and potential parasite intermediate hosts do not overlap. Similar spatial partitioning can be expected in other regions where closely related macrourids occur (e.g. M. caml and $M$. whitsoni). Despite their close geographical distribution, the parasite fauna of $M$. whitsoni differs from that of $M$. carinatus and $M$. holotrachys. The reason might be found in the hydrographic characteristics of the Antarctic Convergence, which functions as a barrier for most animals, including fish, with $M$. whitsoni occurring within and M. carinatus and $M$. holotrachys outside of this barrier. While marine mammals (e.g. cetaceans, pinnipeds) can overcome this barrier and with them their parasites (e.g. different nematodes), for teleosts and their affiliated parasites, e.g. most digeneans, this is not possible. This explains the high percentage of animals being unique and endemic within this border [120]. Due to its isolated location geographically, oceanographically, bathymetrically and thermally, the Antarctic shelf is highly valuable for studying evolutionary mechanisms and can be compared to ancient rift lakes (e.g. Lake
Tanganyika) with endemic species flocks [121]. To extend our knowledge and to test whether the same pronounced endemic patterns occur in other fish species inhabiting this unique ecosystem, further studies are underway.

\section{Conclusions}

The study helped to shed light on the remote and isolated Antarctic realm, with a focus on the ecology of Macrourus whitsoni and its diverse parasite fauna. The comparison with closely related species of Coryphaenoides and Macrourus helped to emphasize the endemically dominated parasite fauna within the Antarctic Convergence. We hope that our findings may not only help generating knowledge on the isolation patterns of Macrourus whitsoni, but also stimulate further research on other deep-sea fish species in this unique environment.

\section{Additional files}

\section{Additional file 1: PCR amplification and species identification} (DOCX $16 \mathrm{~kb}$ )

Additional file 2: Table S1. Parasite taxa in species of Coryphaenoides and Macrourus based on literature data. (DOCX 57 kb)

\section{Acknowledgements}

We thank Sebastian Emde for his help during the fish sampling process and Marlena Görg for examining the fish samples and helping with parasite identification. We also thank Dr. Charles K Blend and Dr. Norman Dronen for their valuable comments on the manuscript.

\section{Funding}

The present study was financially supported by the Institute for Integrative Parasitology and Zoophysiology, Goethe-University, Frankfurt/Main.

\section{Availability of data and materials}

The dataset supporting the conclusions of this article is included within the article and its Additional files. The sequences for Pseudoterranova decipiens $E$ [22] are submitted in the GenBank database under the accession numbers KX378173 and KX378174.

\section{Authors' contributions \\ JM, JK, TK, SK designed the study. JM, JK conducted the analyses. JM, JK, SK, RK, TK wrote the manuscript. All authors read and approved the final manuscript.}

\section{Competing interests}

The authors declare that they have no competing interests.

\section{Consent for publication}

Not applicable.

\section{Ethics approval and consent to participate}

Approval of our present study by a review board institution or ethics committee was not necessary because all fish were caught during a regular research cruise on board of the RV Polarstern. No living animals were used. All fish were expertly killed according to the German Animal Protection Law (§4) and the ordinance of slaughter and killing of animals

(Tierschlachtverordnung § 13).

Received: 18 March 2016 Accepted: 10 July 2016

Published online: 20 July 2016 


\section{References}

1. Marshall NB. Systematic and biological studies of the macrourid fishes (Anacanthini-Teleostii). Deep Sea Res Oceanogr Abstr. 1965;12:299-322.

2. McLellan T. Feeding strategies of the macrourids. Deep Sea Res. 1977;24: 1019-36.

3. Cohen DM, Inada T, Iwamoto T, Scialabba N. Gadiform Fishes of the World (Order Gadiformes). An Annotated and Illustrated Catalogue of Cods, Hakes, Grenadiers and Other Gadiform Fishes Known to Date. FAO; 1990.

4. Massutí E, Morales-Nin B, Stefanescu C. Distribution and biology of five grenadier fish (Pisces: Macrouridae) from the upper and middle slope of the northwestern Mediterranean. Deep Sea Res Part Oceanogr Res Pap. 1995;42: 307-30.

5. Froese R, Pauly D. FishBase. World Wide Web Electron. Publ. www.fishbase org. 2015

6. Palm HW, Klimpel S. Metazoan fish parasites of Macrourus berglax Lacepède, 1801 and other macrourids of the North Atlantic: Invasion of the deep sea from the continental shelf. Deep Sea Res Part II Top Stud Oceanogr. 2008; 55:236-42

7. Hemmingsen W, MacKenzie K. The parasite fauna of the Atlantic cod, Gadus morhua L. Adv Mar Biol. 2001:40:1-80

8. Parker GA, Chubb JC, Ball MA, Roberts GN. Evolution of complex life cycles in helminth parasites. Nature. 2003:425:480-4.

9. Griffiths HJ. Antarctic marine biodiversity - what do we know about the distribution of life in the Southern Ocean? PLoS One. 2010;5:e11683.

10. Gon O, Heemstra PC. Fishes of the southern ocean. JLB Smith Institute of Ichthyology Grahamstown; 1990.

11. Zdzitowiecki K. Occurrence of digeneans in open sea fishes off the South Shetland Islands and South Georgia, and a list of fish digeneans in the Antarctic. Pol Polar Res. 1991;12:55-72.

12. Zdzitowiecki K. Antarctic acanthocephala. Koenigstein: Koeltz Scientific Books; 1991

13. Zdzitowiecki K, Cielecka D. Digenea of fishes of the Weddell Sea. I. Parasites of Macrourus whitsoni (Gadiformes, Macrouridae). Acta Parasitol. 1997:42:23-30

14. Rocka A, Zdzitowiecki K. Cestodes in fishes of the Weddell Sea. Acta Parasitol. 1998:43:64-70.

15. Rocka A. Nematodes of the Antarctic fishes. Pol Polar Res. 2004;25:135-52.

16. Sokolov SG, Gordeev II. New data on trematodes (Plathelminthes, Trematoda) of fishes in the Ross Sea (Antarctic). Invert Zool. 2013;10(3):255-67.

17. Hyslop EJ. Stomach contents analysis - a review of methods and their application. J Fish Biol. 1980;17:411-29.

18. Pinkas L, Oliphant MS, Iverson ILK. Food habits study. Fish Bull. 1971;152:5-10.

19. Bush AO, Lafferty KD, Lotz JM, Shostak AW. Parasitology meets ecology on its own terms: Margolis et al. revisited. J Parasitol. 1997;83:575-83.

20. Klimpel S, Busch MW, Kellermanns E, Kleinertz S, Palm H. Metazoan Deep Sea Fish Parasites. Germany: Verlag Natur \& Wissenschaft; 2009.

21. Clarke KR, Gorley RN. Primer V6: User manual/tutorial. Primer-E. Plymouth; 2006.

22. Bullini L, Arduino P, Cianchi R, Nascetti G, D'Amelio S, Mattiucci S, Paggi L, Orecchia P, Plötz J, Berland B, Smith JW, Brattey J. Genetic and ecological research on Anisakid endoparasites of fish and marine mammals in the Antarctic and Arctic-boreal regions. In: Battaglia B, Valencia J, Walton DWH editors. Antarctic Communities: Species, Structure and Survival. Cambridge: Cambridge University Press; 1997. p. 39-44.

23. Timi JT, Paoletti M, Cimmaruta R, Lanfranchi AL, Alarcos AJ, Garbin L, et al. Molecular identification, morphological characterization and new insights into the ecology of larval Pseudoterranova cattani in fishes from the Argentine coast with its differentiation from the Antarctic species, $P$. decipiens sp. E (Nematoda: Anisakidae). Vet Parasitol. 2014;199:59-72.

24. Kabata Z. A new genus and species of trematode parasitic in Macrurus fabrici (Sundeval), a deep-sea fish. Proc Zool Soc Lond Wiley Online Library; 1961. p. 285-292.

25. Zubchenko AV. Parasitic fauna of some Macrouridae in the Northwest Atlantic. J Northwest Atl Fish Sci. 1981:2:67-72.

26. Klimpel S, Palm HW, Busch MW, Kellermanns E, Rückert S. Fish parasites in the Arctic deep-sea: Poor diversity in pelagic fish species vs. heavy parasite load in a demersal fish. Deep Sea Res Part Oceanogr Res Pap. 2006;53:1167-81.

27. Zubchenko AV. On the fauna of Macrouridae parasites in North Atlantic Tr Poljarn Nauchno-Issled Inst Morsk Rybn Choz Okeanogri PINRO. 1975;35:234-8.

28. Bray RA. Digenea in marine fishes from the eastern seaboard of Canada. J Nat Hist. 1979;13:399-431.
29. Campbell RA. A new digenetic trematode, Gibsonia borealis sp. n. (Lepocreadiidae: Lepidapedinae), parasitic in the rattail Macrourus berglax from the Flemish Cap off Newfoundland. J Helminthol Soc Wash. 1992:59:5-8.

30. Houston KA, Haedrich RL. Food habits and intestinal parasites of deep demersal fishes from the upper continental slope east of Newfoundland, northwest Atlantic Ocean. Mar Biol. 1986;92:563-74.

31. Campbell RA, Correia SJ, Haedrich RL. A new monogenean and cestode from the deep-sea fish, Macrourus berglax Lacépède, 1802, from the Flemish Cap off Newfoundland. Proc Helminthol Soc Wash. 1982;49:169-75.

32. Parukhin AM. Helminths of benthic fish of the Southern Ocean. Kiev: Naukowa Dumka; 1989. p. 7-107.

33. Moravec F, Klimpel S, Kara E. Neoascarophis macrouri n. sp. (Nematoda: Cystidicolidae) from the stomach of Macrourus berglax (Macrouridae) in the eastern Greenland Sea. Syst Parasitol. 2006;63:229-35.

34. Moravec F, Klimpel S. New data on the morphology of Spinitectus oviflagellis Fourment, 1884 (Nematoda: Cystidicolidae) from the pyloric caeca of Macrourus berglax (Macrouridae) in the eastern Greenland Sea. Syst Parasitol. 2007;67:43-50.

35. Ho J-S. Copepod parasites of deep-sea benthic fishes from the western North Atlantic. Parasitology. 1985;90:485-97.

36. Priebe K. Befall des nordatlantischen Grenadierfisches Macrourus berglax mit einem Kopepoden der Gattung Sphyrion. Arch Lebensm-Hyg. 1980;31:144-6.

37. Bakay YI. On infestation of marine redfishes (Sebastes genus) of the North Atlantic by the copepod Sphyrion lumpi (Krøyer, 1845). Proc Workshop Sphyrion Lumpi Krøyer 1845 Güstrow GDR; 1989. p. 29-36.

38. Gaevskaya AV, Rodjuk GN. Ecological characteristics of the parasitofauna of the macrourid Macrourus carinatus Günther in the South Atlantic. Nauchnye Dokl Vysshei Shkoli Biol Nauki. 1988;2:21-5.

39. Gaevskaya AV, Rodjuk GN. New and rare trematode species from deep-sea fishes of the south west Atlantic. Vestn Zool. 1988;5:11-5.

40. Mamaev YL, Parukhin AM, Zubtschenko AV. Diclidophora paracoelorhynch and $D$. attenuata, new species of monogeneans from macrourid fishes. Tr Gelmitologicheskoi Lab. 1979:29:97-102.

41. Rubec LA, Dronen NO. Revision of the genus Diclidophora Krøyer, 1838 (Monogenea: Diclidophoridae), with the proposal of Macrouridophora n. g. Syst Parasitol. 1994;28:159-85.

42. Gaevskaya AV, Rodjuk GN. A new data on fish trematode fauna of the south-west Atlantic. Parazitologiya. 1983;3:28-32

43. Zdzitowiecki K, Cielecka D. Digenea of the fish, Macrourus holotrachys (Gadiformes, Macrouridae) from the North Scotia Ridge, sub-Antarctic Acta Parasitol. 1998;43:200-8.

44. Gaevskaya AVI, Kovaleva AA. Data on the trematodes of fish from the south-western Atlantic. Vestn Zool. 1978;3:60-6.

45. Rohde K, Hayward C, Heap M. Aspects of the ecology of metazoan ectoparasites of marine fishes. Int J Parasitol. 1995;25:945-70.

46. Rohde K, Ho J-S, Smales L, Williams R. Parasites of Antarctic fishes: Monogenea, Copepoda and Acanthocephala. Mar Freshw Res. 1998;49:121-5.

47. Rodjuk G. New species of Acanthocephala of the genus Echinorhynchus (Echinorhynchidae) from the southwestern Atlantic. Parazitologiya. 1986;20:224-7.

48. Stadler T. Contribucion al conocimiento de los parasitos de la fauna Antarctica. Parte II Lophoura szidati n. sp. Parasito Macrourus holotrachys Gunther Crustac Sphyriidae En Pisces Macrouridae. Contrib Inst Antarct Argent. 1978;230:1-13.

49. Walter T, Palm H, Piepiorka S, Rückert S. Parasites of the Antarctic rattail Macrourus whitsoni (Regan, 1913) (Macrouridae, Gadiformes). Polar Biol. 2002;25:633-40.

50. Zdzitowiecki K. Antarctic Digenea, parasites of fishes. Koenigstein: Koeltz Scientific Books; 1997

51. Rocka A. The tetraphyllidean cercoids from teleosts occurring in the Weddell Sea (Antarctic). Acta Parasitol. 1999;44:115-8.

52. Zdzitowiecki K. Acanthocephala in fish in the Weddell Sea (Antarctic). Acta Parasitol. 1996;41:199-203.

53. McCauley JE, Pequegnat JE. Two new species of Dinosoma Manter, 1934 (Trematoda: Hemiuridae) from deep-water macrourid fishes off the coast of Oregon. J Parasitol. 1968:54:931-4.

54. McCauley JE. Six Species of Lepidapedon Stafford, 1904 (Trematoda: Lepocreadiidae) from Deep-Sea Fishes. J Parasitol. 1968:54:496-505.

55. Mamaev YL, Lyadov VN. Monogeneans of the subfamily Diclidophoropsinae (Monogenoidea, Diclidophoridae). Tr Biol-Pochv Inst Vladivostok Nov Ser. 1975;26:115-25. 
56. Solovjeva G. Metabronema insulanum sp. n. (Nematoda, Spirurina) a parasite of deep-water fishes from the Pacific. Moscow: Mezhdunarodnaya Kniga; 1991.

57. Campbell RA, Haedrich RL, Munroe TA. Parasitism and ecological relationships among deep-sea benthic fishes. Mar Biol. 1980;57:301-13.

58. Campbell RA, Munroe TA. New hemiurid trematodes from deep-sea benthic fishes in the western North Atlantic. J Parasitol. 1977;63:285-94.

59. Campbell RA, Bray RA. Lepidapedon spp. (Digenea: Lepocreadiidae) from deep-sea gadiform fishes of the NW Atlantic Ocean, including four new species. Syst Parasitol. 1993;24:99-110.

60. Bray RA, Gibson DI. The Lepocreadiidae (Digenea) of fishes from the north-east Atlantic: a review of the genus Lepidapedon Stafford, 1904. Syst Parasitol. 1995;31:81-132.

61. Bray RA, des Clers SA. Multivariate analyses of metrical features in the Lepidapedon elongatum (Lebour, 1908) species-complex (Digenea, Lepocreadiidae) in deep and shallow water gadiform fishes of the NE Atlantic. Syst Parasitol. 1992;21:223-32

62. Bray RA, Gibson DI. The Acanthocolpidae (Digenea) of fishes from the north-east Atlantic: the status of Neophasis Stafford, 1904 (Digenea) and a study of North Atlantic forms. Syst Parasitol. 1991;19:95-117.

63. Palm H. Untersuchungen zur Systematik von Rüsselbandwürmern (Cestoda: Trypanorhyncha) aus atlantischen Fischen. Institut für Meereskunde; 1995.

64. Ho J-S. Chondracanthid copepods (Poecilostomatoida) parasitic on Japanese deep-sea fishes, with a key to the genera of the Chondracanthidae. J Nat Hist. 1994;28:505-17.

65. Bray RA. Steringophorus Odhner, 1905 (Digenea: Fellodistomidae) in deep-sea fishes from the northeastern Atlantic, with the description of Steringophorus margolisi n. sp. Can J Fish Aquat Sci. 1995;52:71-7.

66. Kritsky DC, Klimpel S. Cyclocotyloides bergstadi n. sp. (Monogenoidea: Diclidophoridae: Diclidophoropsinae) from the Gills of Grenadier, Coryphaenoides brevibarbis (Teleostei: Macrouridae), in the Northeast Atlantic Ocean. Comp Parasitol. 2007;74:23-30.

67. Bray RA, Campbell RA. New plagioporines (Digenea: Opecoelidae) from deep-sea fishes of the North Atlantic Ocean. Syst Parasitol. 1996;33:101-13.

68. Bray RA, Campbell RA. Fellodistomidae and Zoogonidae (Digenea) of deepsea fishes of the NW Atlantic Ocean. Syst Parasitol. 1995;31:201-13.

69. Campbell RA. New tetraphyllidean and trypanorhynch cestodes from deepsea skates in the western North Atlantic. Proc Helminthol Soc Wash. 1977. 44:191-3.

70. Blend CK, Dronen NO, Armstrong HW. Six new species of Lepidapedon Stafford, 1904 (Digenea: Lepocreadiidae) from deep-sea macrourid fishes from the Gulf of Mexico and Caribbean Sea, with revised keys to the species of the genus. Syst Parasitol. 2000;45:29-51.

71. Ho J, Kim I-H. Lophoura (Copepoda: Sphyriidae) parasitic on the rattails (Pisces: Macrouridae) in the Pacific, with note on Sphyrion lumpi from the Sea of Japan. Publ Seto Mar Biol Lab. 1989;34(1/3):37-54.

72. Bray RA, Gibson DI. The Lepocreadiidae Odhner, 1905 (Digenea) of fishes from the north-east Atlantic: summary paper, with keys and checklists. Syst Parasitol. 1997;36:223-8.

73. Machida M, Kamegai S. Digenean trematodes from deep-sea fishes of Suruga Bay, central Japan. Natl Sci Mus Monogr. 1997;12:19-30.

74. Ho J-S. New species of Clavella (Copepoda: Lernaeopodidae) parasitic on Japanese rattails (Pisces: Macrouridae). Publ Seto Mar Biol Lab. 1993;36(3): 107-18.

75. Gibson DI. Allopodocotyle margolisi n.sp. (Digenea: Opecoelidae) from the deep-sea fish Coryphaenoides (Chalinura) mediterraneus in the northeastern Atlantic. Can J Fish Aquat Sci. 1995;52:90-4.

76. Kellermanns E, Klimpel S, Palm H. Parasite fauna of the Mediterranean grenadier Coryphaenoides mediterraneus (Giglioli, 1893) from the MidAtlantic Ridge (MAR). Acta Parasitol. 2009;54:158-64.

77. Moravec F, Klimpel S. Two new species of cystidicolid nematodes from the digestive tract of the deep-sea fish Coryphaenoides mediterraneus (Giglioli) (Macrouridae) from the Mid-Atlantic Ridge. Syst Parasitol. 2009;73: 37-47.

78. Mauchline J, Gordon JDM. Feeding and bathymetric distribution of the gadoid and morid fish of the Rockall Trough. J Mar Biol Assoc U K. 1984;64: 657-65

79. Blend CK. The digenetic trematodes parasitizing macrourid fishes from the Gulf of Mexico and Caribbean Sea: an examination of their systematics, zoogeography and host-parasite ecology. College Station: Texas A\&M University; 1996
80. Szuks H. Zum Befall von Macrourus rupestris (Gunnerus) aus dem Bereich von Labrador mit digenen Trematoden. Wiss Z Pädagog Hochsch Lise Herrmann. 1975;2:225-31.

81. Szuks H. Verwendbarkeit von Parasiten zur Gruppentrennung beim Grenadierfisch Macrourus rupestris. Angew Parasitol; 1980.

82. Gaevskaya AV. Two new species of trematodes Gonocerca macrouri sp. n. and Hemiurus macrouri sp. $n$. from Macrourus rupestris $L$. of the north-east Atlantic. Parazitologiya. 1975;9:457-9.

83. Zubchenko AV. Use of parasitological data in studies of the local grouping of rock Grenadier, Coryphaenoides rupestris Gunner. Natl Oceanogr Atmospheric Tech Rep NMFS; 1985.

84. Gibson DI, Bray RA. Hemiuridae (Digenea) of fishes from the north-east Atlantic. British Museum (Natural History); 1986.

85. Bray RA, Gibson DI. The Accacoeliidae (Digenea) of fishes from the northeast Atlantic. Trustees of the British Museum (Natural History); 1977.

86. Pascoe PL. Monogenean parasites of deep-sea fishes from the Rockall Trough (N.E. Atlantic) including a new species. J Mar Biol Assoc UK. 1987:67: 603-22

87. Noble ER, Orias JD, Rodella TD. Parasitic fauna of the deep-sea fish, Macrourus rupestris (Gunnerus) from Korsfjorden, Norway. Sarsia. 1972;50: 47-50.

88. Køie M. Nematode parasites in teleosts from 0 to $1540 \mathrm{~m}$ depth off the Faroe islands (The North Atlantic). Ophelia. 1993;38:217-43.

89. Petter AJ, Køie M. Fellicola longispiculus gen. nov., sp. nov. (Nematoda, Rhoabdochonidae) from the gall bladder of the marine fish Coryphaenoides rupestris. Ann Parasitol Hum Comp. 1993;68:226-8.

90. Rohde K, Williams A. Taxonomy of monogeneans of deep sea fishes in southeastern Australia. Syst Parasitol. 1987;10:45-71.

91. Rohde K. Gill Monogenea of deepwater and surface fish in southeastern Australia. Hydrobiologia. 1988;160:271-83.

92. Bray RA. The bathymetric distribution of the digenean parasites of deep-sea fishes. Folia Parasitol Praha. 2004;51:268-74.

93. Rubec LA, Blend CK, Dronen NO. Syncoelicotyloides zaniophori n. sp. (Monogenea: Microcotylidae) from the Gills of Coryphaenoides zaniophorus (Macrouridae) from the Gulf of Mexico. J Parasitol. 1995;81:957-60.

94. Romero RC. Paeon triakis sp $\mathrm{n}$. and a new form for Lateracanthus quadripedis Kabata et Gusev, 1966 (Copepoda, Siphonostomatoida), parasitic on Chilean fishes in the South Pacific. Acta Parasitol. 2001:46:24-9.

95. Kuramochi T. Digenean trematodes of fishes from deep-sea areas off the Pacific coast of northern Honshu. Japan Natl Mus Nat Sci Monogr. 2009;25-37.

96. Mamaev IL, Brashovian PP. Syncoelicotyloides macruri gen. et sp. n. - the first representative of the subfamily Syncoelidotylinae (Microcotylidae, Monogenea) from macruriform fishes. Parazitologiya. 1989;23:532-6.

97. Gaevskaya AV, Kovaleva AA. Special features of the monogenean fauna of the southwest Atlantic. Investigation of monogeneans in the USSR; 1977. p. 102-104.

98. Polyanskii YI. Data on the parasitology of fishes from the northern seas of USSR. Parasites in Barents Sea. Tr Zool Inst Akad Nauk SSSR. 1955;19:1-170.

99. Palm HW, Reimann N, Spindler M, Plötz J. The role of the rock cod Notothenia coriiceps Richardson, 1844 in the life-cycle of Antarctic parasites. Polar Biol. 1998;19:399-406.

100. Rocka A. Helminths of Antarctic fishes: Life cycle biology, specificity and geographical distribution. Acta Parasitol. 2006;51:26-35.

101. Rocka A. Cestodes of the Antarctic fishes. Pol Polar Res. 2003;24:261-76.

102. Laskowski Z, Rocka A, Zdzitowiecki K, Ghigliotti L, Pisano E. New data on the occurrence of internal parasitic worms in the Gymnodraco acuticeps and Cygnodraco mawsoni (Bathydraconidae) fish in the Ross Sea, Antarctica. Pol Polar Res. 2005;26:37-40.

103. Zdzitowiecki K, Ozouf-Costaz C. Contribution to the knowledge of the parasitic fauna of fish off Adelie Land, Antarctica. Pol Polar Res. 2013;34:429-35.

104. Zdzitowiecki K. Diversity of Digenea, parasites of fishes in various areas of the Antarctic. In: di Prisco G., Pisano E. \& Clarke A. (editors) Fishes of Antarctica. A biological overview. Springer-Verlag Italia; 1998. p. 87-94.

105. des Clers S, Andersen K. Sealworm (Pseudoterranova decipiens) transmission to fish trawled from Hvaler, Oslofjord, Norway. J Fish Biol. 1995:46:8-17.

106. Palm HW. Ecology of Pseudoterranova decipiens (Krabbe, 1878)(Nematoda: Anisakidae) from Antarctic waters. Parasitol Res. 1999;85:638-46.

107. Rokicki J, Rodjuk G, Zdzitowiecki K, Laskowski Z. Larval ascaridoid nematodes (Anisakidae) in fish from the South Shetland Islands (Southern Ocean). Pol Polar Res. 2009;30:49-58. 
108. Klöser H, Plötz J, Palm H, Bartsch A, Hubold G. Adjustment of anisakid nematode life cycles to the high Antarctic food web as shown by Contracaecum radiatum and C. osculatum in the Weddell Sea. Antarct Sci. 1992:4:171-8.

109. Zdzitowiecki K, Presler P. Occurrence of Acanthocephala in intermediate hosts, Amphipoda, in Admiralty Bay, South Shetland Islands, Antarctica. Pol Polar Res. 2001;22:205-12.

110. Zdzitowiecki K. Acanthocephala occurring in intermediate hosts, amphipods, in Admiralty Bay (South Shetland Islands, Antarctica). Acta Parasitol. 2001;46:202-7.

111. Brickle P, MacKenzie K, Pike A. Parasites of the Patagonian toothfish, Dissostichus eleginoides Smitt 1898, in different parts of the Subantarctic. Polar Biol. 2005;28:663-71.

112. Palm HW, Klimpel S, Walter T. Demersal fish parasite fauna around the South Shetland Islands: high species richness and low host specificity in deep Antarctic waters. Polar Biol. 2007;30:1513-22.

113. Silveira T, Bianchini $A$, Robaldo R, Colares EP, Muelbert MMC, Martìnez PE, et al. Corynosoma spp. (Acanthocephala, Polymorphidae) in Mirounga leonina (Pinnipedia, Phocidae) of South Shetlands Islands: a new host for Corynosoma cetaceum. Pan-Am J Aquat Sci. 2014;9:66-9.

114. Pinkerton MH, Forman J, Stevens DW, Bury SJ, Brown J. Diet and trophic niche of Macrourus spp. (Gadiformes, Macrouridae) in the Ross Sea region of the Southern Ocean. J Ichthyol. 2012;52:787-99.

115. Würzberg L, Peters J, Flores $H$, Brandt A. Demersal fishes from the Antarctic shelf and deep sea: A diet study based on fatty acid patterns and gut content analyses. Deep Sea Res Part II Top Stud Oceanogr. 2011;58:2036-42.

116. Laskowski Z, Jeżewski W, Zdzitowiecki K. New data on the occurrence of Acanthocephala in Antarctic Amphipoda. Acta Parasitol. 2010;55:161-6.

117. Busch MW, Kuhn T, Münster J, Klimpel S. Marine crustaceans as potential hosts and vectors for metazoan parasites. Arthropods Vectors Emerg Dis Springer; 2012. p. 329-360.

118. Fenaughty JM, Stevens DW, Hanchet SM. Diet of the Antarctic toothfish (Dissostichus mawsoni) from the Ross Sea, Antarctica (subarea 88.1). CCAMLR Sci. 2003;10:113-23.

119. Laptikhovsky W. A trophic ecology of two grenadier species (Macrouridae, Pisces) in deep waters of the Southwest Atlantic. Deep Sea Res Part Oceanogr Res Pap. 2005;52:1502-14.

120. Mackintosh NA. The pattern of distribution of the Antarctic fauna. Proc $R$ Soc Lond B Biol Sci. 1960;152:624-31.

121. Eastman JT, McCune AR. Fishes on the Antarctic continental shelf: evolution of amarine species flock? J Fish Biol. 2000;57:84-102.

\section{Submit your next manuscript to BioMed Central and we will help you at every step:}

- We accept pre-submission inquiries

- Our selector tool helps you to find the most relevant journal

- We provide round the clock customer support

- Convenient online submission

- Thorough peer review

- Inclusion in PubMed and all major indexing services

- Maximum visibility for your research

Submit your manuscript at www.biomedcentral.com/submit

C Biomed Central 